Since glacier slides on this scale must necessarily be rare occurrences it is interesting to see whether any meteorological explanation can be found in this case. I am indebted to Professor P. Veyret of the Institut de Géographie Alpine of Grenoble for the information in the following tables.

\begin{tabular}{|c|c|c|c|c|c|c|c|c|c|}
\hline \multicolumn{10}{|c|}{$\begin{array}{c}\text { TABLE I } \\
\text { Mean temperatures }\left({ }^{\circ} \mathrm{C} .\right) \text { at Le Tour }(1460 \mathrm{~m} .)\end{array}$} \\
\hline & Year & & & 1944 & '945 & 1946 & I 947 & I 948 & I 949 \\
\hline $\begin{array}{l}\text { June, July, } \\
\text { August }\end{array}$ & $\begin{array}{c}\text { August } \\
. .\end{array}$ & $\begin{array}{l}. . \\
. .\end{array}$ & $\because$ & $\begin{array}{l}13.8 \\
16.1\end{array}$ & $\begin{array}{l}13.2 \\
18.0\end{array}$ & $1 \overline{8.0}$ & $\begin{array}{l}16 \cdot 6 \\
18.5\end{array}$ & $\frac{-}{13.9}$ & $\begin{array}{l}13.9 \\
14.7\end{array}$ \\
\hline
\end{tabular}

TABLE II

\begin{tabular}{|c|c|c|c|c|c|c|c|c|c|}
\hline \multicolumn{10}{|c|}{ Day temperatures $\left({ }^{\circ} \mathrm{C}.\right)$ at Le Tour, August 1949} \\
\hline Day & & 10 & II & 12 & 13 & $14^{*}$ & 15 & I6 & 17 \\
\hline 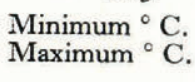 & $\ldots$ & $\begin{array}{l}135 \\
225\end{array}$ & $\begin{array}{r}85 \\
205\end{array}$ & & $\begin{array}{r}1 \\
14\end{array}$ & $\begin{array}{r}1 \\
16\end{array}$ & $\begin{array}{r}5 \\
21\end{array}$ & $\begin{array}{r}7 \\
22\end{array}$ & $\begin{array}{c}6 \\
22 \cdot 5\end{array}$ \\
\hline
\end{tabular}

Table I shows that although the summer of 1949 was hotter than that of 1948 it was actually cooler than those of the preceding years. However, from the minimum and maximum daily temperatures of the month (Table II) it is seen that the slide occurred in the middle of a cold spell with a minimum of $\mathrm{I}^{\circ} \mathrm{C}$. at $\mathrm{I} 450 \mathrm{~m}$. on the day of the slide. On the basis of the I.C.A.N. dry adiabatic lapse rate of $\mathrm{I} \cdot 98^{\circ} \mathrm{C}$. $/ 1000 \mathrm{ft}$. $\left(6 \cdot 5^{\circ} \mathrm{C}\right.$. $/ \mathrm{km}$.) this means a minimum of $-4^{\circ} \mathrm{C}$. at the height of the breakaway, $2200 \mathrm{~m}$. The cause of the slide is thus most probably to be found in the succession of warm days and cold nights which preceded the occurrence. This would cause repeated melting and freezing (expansion) of the ice in the glacial cracks thus driving the lower part of the glacier forward with a wedge or ratchet-like action into an unstable position. $\dagger$

MS. received 8 fune $195^{\circ}$

† Mons. P. Guichonnet in an account of the slide in the Revue de Géographie Alpine, Grenoble (Tome 38 , Fasc. 4 , 1950, p. 198-201), reaches the same conclusion, but suggests that the very hot summer of r 947 may have loosened the
adhesion of the glacier sole.

Another factor was suggested by Mons. Messines du Sourbier, President of the Glaciological Sub-section of the Société Hydrotechnique de France (Mémoires et Travaux, Vol. 1, 1950, p. 56-60). According to this the recent recession of the glacier had brought the snout out of a gully in which it lay firm thus damming the ice stream, on to a steep open-
faced cliff above and so removing the dam.

The two accounts quoted in this note provide certain other details to which those interested are referred.- $-E d$.

\title{
THE INTERNATIONAL SNOW CLASSIFICATION
}

AT its meeting in Oslo in 1948 the International Commission on Snow and Glaciers passed a resolution that "attempts should be made to standardize a system of snow cover measurement." As a preliminary step a Committee was set up to consider a suitable classification of snow. Its members were Mr. V. J. Schaefer (United States), Mr. G. J. Klein (Canada) and Dr. M. de Quervain (Switzerland).

In the autumn of 1949 the Committee produced a tentative snow classification, the aim of which was "to promote uniformity in the method of describing snow and to simplify the correlation of data obtained by different groups." Comments and suggestions were invited for improving it, and the tentative form was put into operation for a time in America in order to expose any flaws.

The Committee sent this classification to the British Glaciological Society requesting comments and criticisms. A Meeting of the Society was accordingly arranged and took place in May 
I950 attended by many glaciologists and meteorologists. Dr. de Quervain came over from Switzerland for the Meeting. He explained the principles which had guided the Committee and answered numerous questions.

The classification was generally approved, with certain minor reservations and some suggestions for its improvement. These, together with comments from other sources, are now (December 1950) being considered. After all points have been finally settled the full classification will be published in this Journal.

\title{
EARLY D I C OVERERS
}

\author{
V \\ LOUIS AGASSIZ ON “EXTRUSION FLOW”,
}

AgAssiz * evolved, at an early date, a theory of differential movement of the layers in a glacier. In order to explain the differing positions of the beds in the lower and upper sections of the glacier he suggested that the speed of the lower beds in the accumulation or néré region was faster than that of the upper beds. In the ablation region the opposite was the case. These suggestions were not the result of detailed experiments but were brought forward as a hypothesis from a priori argument. After making many observations, it appeared to him that the layers in the upper section sloped downwards, those in the middle were almost horizontal, whilst those at the terminus slope, upwards.

Agassiz believed that this differential movement between the upper and lower layers of a glacier explained the following facts. The bergschrund being filled every season with new snow would tend to form a wedge of névé. This névé, replaced each year by a fresh accumulation, would build up a succession of vertical strata down the glacier. Agassiz argued that the absence of vertical strata could only be due to an increased speed of the lower layers. Again, the differential movement seemed to explain how two stations on the glacier, one in the upper regions and another a little lower, could undergo differential ablation whilst having a similar snow level. Agassiz here implied that the same amount of snow is received at each station, but that the increased level one would expect in the upper station, due to decreased melting, was not found. This, he said, could be explained by an increased speed of the lower layers of the glacier in the upper or cirque region.

The mechanism by which differential movement was made possible was described by Agassiz as a plasticity in the lower layers of the glacier due to the presence of water. This drained through the glacier so that the upper layers were comparatively dry, whilst the lower layers tended to absorb the water, their motion being thus facilitated. The upper layers, being dry, had no such lubricating medium.

Agassiz had no illustions about the difficulties of the hypothesis and at the end of the section he showed his complete lack of dogmatism. "Is this cause which we have indicated sufficient to bring about such a result? It is through future research that we shall perhaps find this out one day."

Department of Geography,

W. R. Battle

Cambridge University

- Agassiz, Louis, Sysidme glaciaire. Nouvelles études et expériences sur les glaciers actuels. Paris, 1847. 